\begin{tabular}{lccc} 
VERSITA & GOSPODARKA & SUROWCAMI & MINERALNYMI \\
\hline \multirow{2}{*}{ Tom 29} & 2013 & Zeszyt 2 \\
& & DOI 10.2478/gospo-2013-0018 &
\end{tabular}

\author{
ALEKSANDRA PALA*, KAMILA WIDZIEWICZ**, JACEK NOWAK***, \\ KRZYSZTOF LOSKA****, JOLANTA BIEGAŃSKA*****
}

\title{
Content analysis of heavy metals/metalloids and mineral composition of waste generated during uranium concentrate processing
}

\begin{abstract}
Introduction
The mining of uranium in Poland has been shrouded in secret for decades. Although the occurrence of uranium deposits in Lower Silesia has been known since the mid XIX Century, the exploitation of uranium ore started in this region only in the 1920s (Nieć 2009). Preceded by a series of radiometric, geochemical, and radiohydrogeochemical testes, exploratory work was also carried out in Kowary, Podgórze, Miedzianka, Radoniów, Kletno, Głuszyca Dolna, and Rudki.

It has been estimated that in the course of exploratory work which in the years 1948-1955 included areas of the Sudety, Karpaty, and Świętokrzyskie Mountains, as well as Upper Silesia Basin and Częstochowa, seventeen uranium deposits and several hundred radioactive anomalies were discovered within Polish territory. Most of them were accessible thanks to a variety of mining techniques, and exploited in the course of the research conducted (Solecki et al. 2011).

* M.Sc., ***** D.Sc., Silesian University of Technology, Faculty of Energy and Environmental Engineering, Department of Technology and Installations for Waste Management, Gliwice, Poland; e-mail: aleksandra.pala@polsl.pl

** M.Sc., **** D.Sc., Silesian University of Technology, Faculty of Energy and Environmental Engineering, Department of Environmental Chemistry and Membrane Processes, Gliwice, Poland.

*** Ph.D., Silesian University of Technology, Faculty of Mining and Geology, Institute of Applied Geology, Gliwice, Poland.
\end{abstract}


The region richest in uranium ore was the Sudety Mountains, with the most promising deposits being "Wolność" (Kowary), "Podgórze" (Podgórze near Kowary), "Radoniów" (Radoniów), “Okrzeszyn" (Okrzeszyn) and "Grzmiąca” (Głuszyca Dolna). Test extractions were conducted at these locations (Miecznik et al. 2011). The magnitude of these deposits was estimated from several dozen to 938 tons of uranium (Miecznik et al. 2011).

At all of these sites, uranium ore was mined using traditional methods, and the waste rock was collected in the form of heaps located in areas adjacent to the mines (Nieć 2009).

Waste rock is a by-product generated during the extraction of uranium ore in surface mines and underground mines during the drilling of sidewalks (Kreusch et al. 2005; Franks et al. 2011; Yilmaz 2011). A certain amount of rock waste formed during the process of crushing and grinding of ore is generated by uranium pre-treatment plants.

Compared to ordinary rocks, waste rock collected as a heap often contains a higher concentration of radionuclides (Giusti 2009). In addition to radioactive substances, waste rock heaps also contain certain amounts of heavy metal elements which as a result of inadequate security of heaps, can escape into the environment, causing lasting contamination (Kulczycka et al. 2003; Kreusch et al. 2005; Chakrabarty-Patra et al. 2011; Neves et al. 2012; Fernandes et al. 1998; Samimi Namin et al. 2011). The mobility of toxic substances present in waste rock dumps and their ability to penetrate into the soil profile is determined by such factors as the quantity of available leaching medium (precipitation), the $\mathrm{pH}$ of waste rock and precipitation, redox potential, surface porosity, and the content of organic and inorganic compounds (Chakrabarty-Patra et al. 2011; Motuzas et al. 2002).

Leaks from waste heaps are particularly dangerous for the preservation of the biological balance of the natural environment. This can occur in the case of a waste rock landfill containing the mineral pyrite $\left(\mathrm{FeS}_{2}\right)($ Kreusch et al. 2005). Sulfuric acid leaching, resulting from the impact of precipitation on the heap, causes not only an elution of heavy metals, but radioactive isotopes as well. These substances penetrate into the environment and may cause contamination of ground-water (Lee, Pandey 2012; Liu et al. 2011).

\section{Area of research}

The sites examined were located in the Jelenia Góra Basin area in south-western Poland in the Lower Silesia province. Waste rock was taken from heaps located in Kowary-Podgórze and Radoniów.

Fig.1. shows the geographical localization of sites where samples of waste rock were collected.

Exploitation of uranium ore in the mine "Podgórze" began in 1951 and continued uninterrupted until 1958. The deposit was located in a tectonic zone, crossing a series of granites accompanied by biotite shales. Uranium minerals were represented by uranophan and autunite which occurred in the form of veins and small nests (Uranium... 2011). 


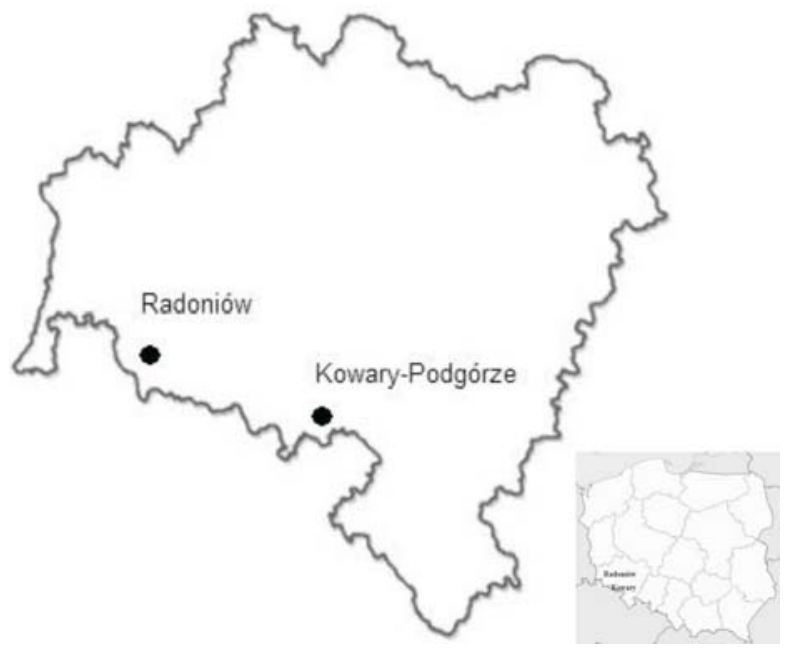

Fig. 1. Map of Lower Silesia and sampling sites

Rys. 1. Mapa Dolnego Śląska z zaznaczonymi miejscami poboru próbek

The "Radoniów" deposit was discovered in 1952, and was one of the richest deposits located in Polish territory. The geology of the deposit was associated with the occurrence of two parallel faults which divided a metamorphic complex formed of gneiss, granite and quartz shales. In these deposits, uranium mineralization was represented by autunite, metauranocircite, and torbernite. The exploitation of uranium ore in Radoniów was concluded in 1963 (Uranium... 2011).

\section{Materials and methods}

\subsection{Materials}

Research material consisted of waste rock generated during the mining and processing of uranium ore. The samples of waste rock were collected from the top layer of the heap at a depth of $20 \mathrm{~cm}$. The research material came from three piles located in Kowary-Podgórze (heaps 19 and 19a, 17, 16) and from the heap in Radoniów. A total of 13 samples of waste rock were collected. Fig. $2-5$ show photographs of waste rock samples.

The samples of waste rock were fragments of metamorphic and magmatic rocks, brown (heaps 19 and 19a, 17, 16) and brown-yellow (heap in Radoniów). The average size of the rock fragments were from 10 to $35 \mathrm{~mm}$. The waste rock taken from the heap 19 and 19a was characterized by more massive texture than other wastes, the structure of which were more porous.

The samples of waste rock were taken from heaps which were subjected to a natural process of rehabilitation. 


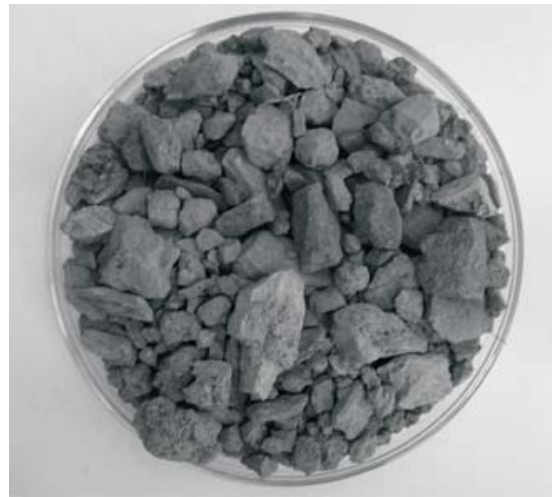

Fig. 2. Sample taken from heap 19 and 19a in Kowary - Podgórze Fig. 2. Próbka pobrana z hałdy 19 i 19a w Kowarach - Podgórzu

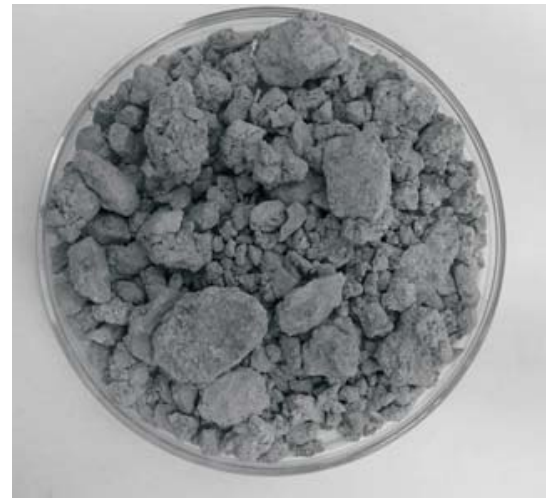

Fig. 3. Sample taken from the heap in Radoniów Rys. 3. Próbka pobrana $\mathrm{z}$ hałdy w Radoniowie

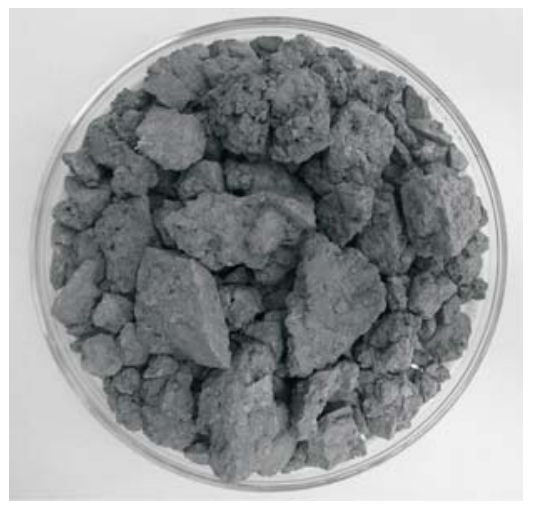

Fig. 4. Sample taken from heap 16 in Kowary - Podgórze Rys. 4. Próbka pobrana z hałdy 16 w Kowarach - Podgórzu 


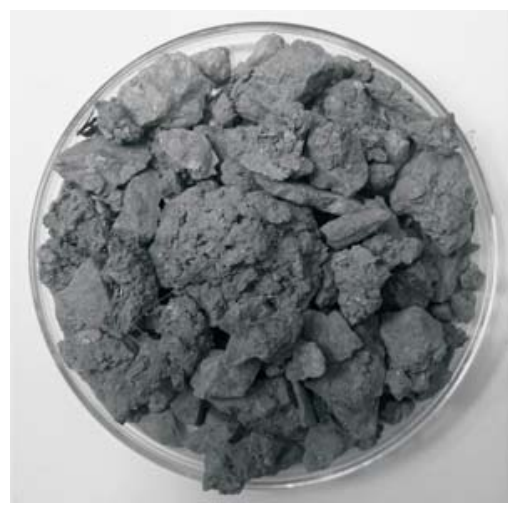

Fig. 5. Sample taken from heap 17 in Kowary - Podgórze

Rys. 5. Próbka pobrana z hałdy 17 w Kowarach - Podgórzu

\subsection{Methods}

The research material was dried in an oven at a temperature of $105^{\circ} \mathrm{C} \pm 0.5$ to a constant mass. After cooling to room temperature, the samples of wastes were milled in a Retsch mill S-1000 to a grain diameter $<0.01 \mathrm{~mm}$.

Determination of mineral composition of the waste rock was possible thanks to the use of X-ray diffraction techniques. X-ray analysis was performed with the use of a DRON HZG-4 diffractometer equipped with a copper lamp with a nickel filter. Diffractograms covered the angular range $2 \Theta$ from 4 to $64^{\circ}$ in steps of $0.05^{\circ}$. Identification of mineral phases in the samples was carried out based on existing records (Bayliss et al. 1986; Gaweł, Muszyński 1996).

In order to determine the concentration of heavy metals/metalloids in the waste rock samples, it was necessary to mineralize the samples using the microwave digestion system MLS-1200 MEGA Milestone. The mineralization process proceeded in two stages:

- second stage - performed in a closed system in a microwave oven, adding to the tested samples $3 \mathrm{~cm}^{3}$ of nitric acid (V) $\left(\mathrm{HNO}_{3}\right)$.

- first stage - performed in an open system on a hot plate, consisted of adding to each sample $1 \mathrm{~cm}^{3}$ of hydrofluoric acid (HF) and heating to a temperature of $208^{\circ} \mathrm{C}$. To evaporate residues of $\mathrm{HF}$ acid, $1 \mathrm{~cm}^{3} \mathrm{HNO}_{3}$ was added to the samples. The operation was repeated twice.

After completion of the mineralization process, the samples were transferred quantitatively to volumetric flasks and supplemented with distilled water to a volume of $50 \mathrm{~cm}^{3}$. The content of heavy metals in the samples of waste rock was determined by atomic sorption spectrometry, with the use of a SpectrAA Varian 880.

In concurrence with the regulations of the Polish Minister of the Environment regarding the quality standards for soil and ground in samples of waste rock, the concentration of the following heavy metals/metalloids was determined: $\mathrm{As}, \mathrm{Cr}, \mathrm{Zn}, \mathrm{Cd}, \mathrm{Co}, \mathrm{Cu}, \mathrm{Ni}$, and $\mathrm{Pb}$ (Regulation of Minister of the Environment... 2002). 


\section{Results and discussion}

\subsection{X-ray analysis}

Table 1 shows the mineral composition of waste samples determined by identifying the phases using X-ray diffraction. Because of the variety in the mineral composition of waste samples, Table 1 presents the results of detailed analysis.

Samples number 1 to 4 were taken from heap 19 and 19a (Kowary-Podgórze), samples 5 to 7 from the heap in Radoniów, samples 8 to 10 were taken from pile 16 (Kowary-Podgórze), and samples 11 to 13 from heap 17 (Kowary-Podgórze).

The symbol "+" used in Table 1 means that in a sample of the waste the mineral has been identified; while the symbol "-" indicates that X-ray analysis did not confirm the presence of minerals in the sample.

Fig. 6-7 present exemplary diffractograms of analyzed samples of the waste. The diffractograms were chosen in a way that best illustrates the variety of the analyzed samples of waste rock.

TABLE 1

The mineral composition of waste rock samples

Skład mineralny pobranych próbek odpadów skalnych

\begin{tabular}{|c|c|c|c|c|c|c|c|c|c|c|c||}
\hline \multirow{2}{*}{$\begin{array}{c}\text { No } \\
\text { sample }\end{array}$} & \multicolumn{10}{|c||}{ Identified mineral } \\
\cline { 2 - 29 } & $\mathrm{Q}$ & $\mathrm{S}$ & $\mathrm{W}$ & $\mathrm{Ph}$ & $\mathrm{Sc}$ & $\mathrm{He}$ & $\mathrm{J}$ & $\mathrm{M} / \mathrm{I}$ & $\mathrm{Ch}$ & $\mathrm{H}$ & $\mathrm{U}$ \\
\hline \hline 1 & + & + & + & + & - & - & + & + & - & - & - \\
\hline 2 & + & + & + & - & - & - & + & - & - & - & + \\
\hline 3 & + & - & + & - & - & - & - & - & - & - & + \\
\hline 4 & + & - & + & - & - & - & - & - & - & - & - \\
\hline 5 & + & + & - & - & - & - & - & - & - & - & - \\
\hline 6 & + & + & + & - & - & - & + & + & + & - & - \\
\hline 7 & + & + & + & + & - & + & - & - & - & - & + \\
\hline 8 & + & + & + & + & - & - & - & - & - & - & + \\
\hline 9 & + & + & + & - & - & - & - & + & + & - & - \\
\hline 10 & + & + & + & - & + & - & - & - & + & + & + \\
\hline 11 & + & + & + & - & + & + & - & + & - & - & - \\
\hline 12 & + & + & + & - & - & - & + & + & + & - & - \\
\hline 13 & + & + & + & - & + & - & + & + & + & - & - \\
\hline
\end{tabular}

Abbreviations of minerals: Q - Quartz, S - Sanidine, W - Wollastonite, Ph - Philipsite, Sc-Scolecite, $\mathrm{He}$ - Heulandite, J - Jordanite, M/I - Muscovite/Illite, Ch - Chamosite, H - Hornblende, U - Uranospinite. 


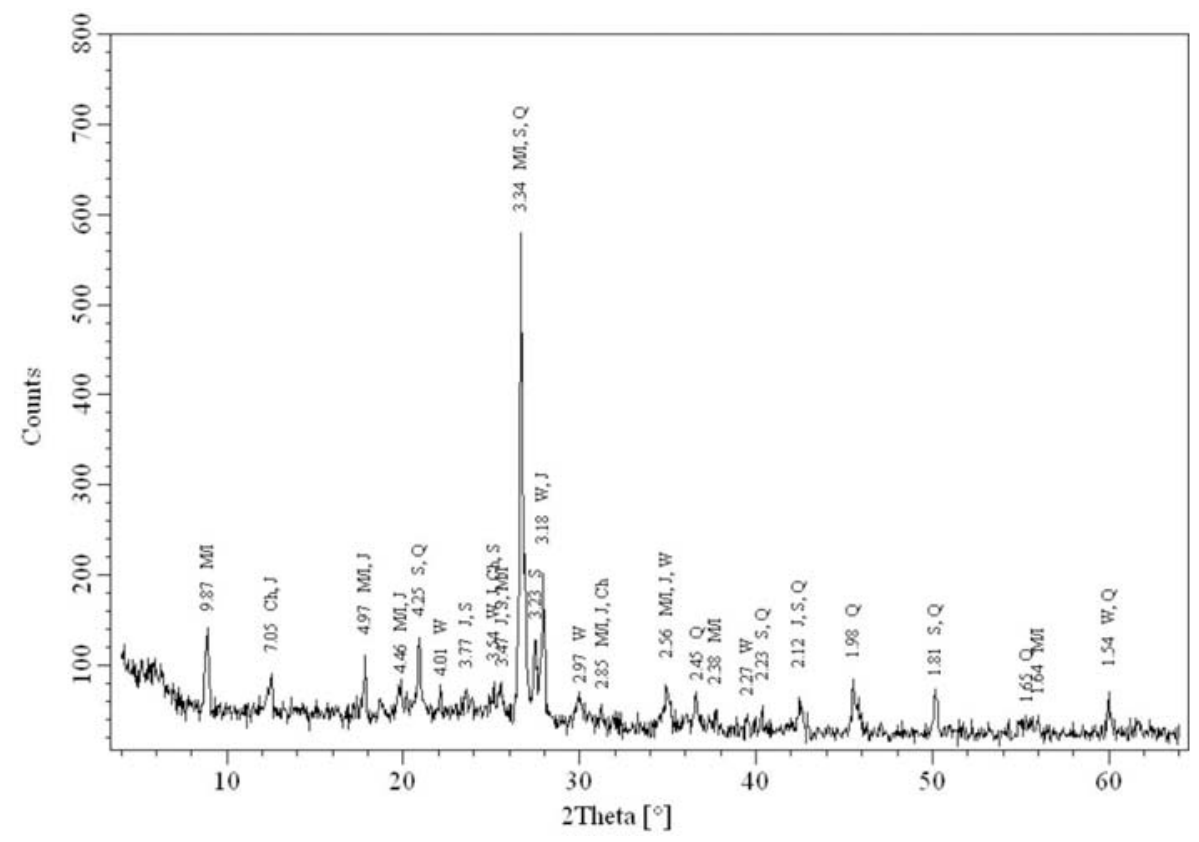

Fig. 6. Diffractogram of sample number 6

Rys. 6. Dyfraktogram próbki odpadów numer 6

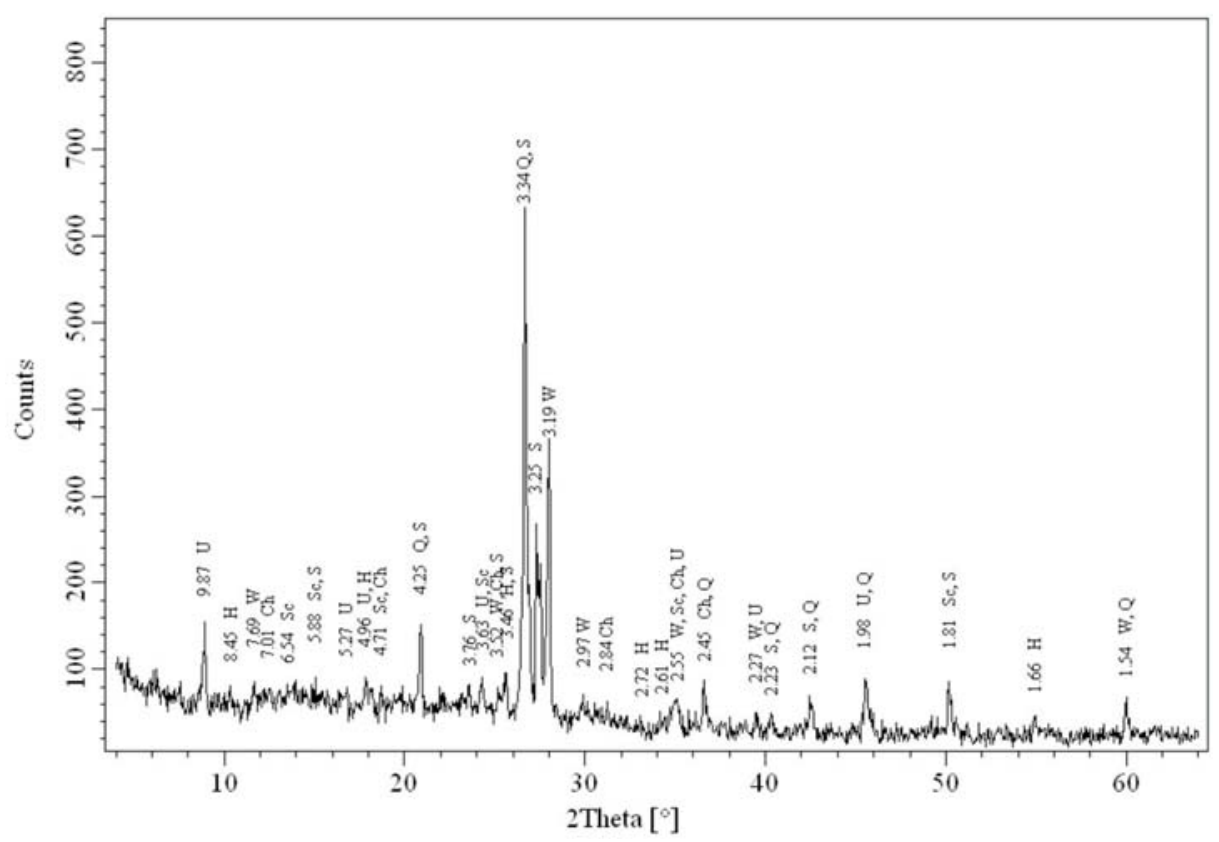

Fig. 7. Diffractogram of sample number 10

Rys. 7. Dyfraktogram próbki odpadów numer 10 
The minerals marked in the samples are compounds which commonly occur in the research area (Lis, Sylwestrzak 1986) and can be assigned to the following groups (Bolewski 1965):

- silicates group - quartz, wollastonite,

- alkali feldspar group - sanidine,

- zeolites group - philipsite, scolecite, heulandite,

- sulfur-lead group - jordanit,

— mica group - muscovite, illite,

- chlorites group - chamosite,

- amphibole group - hornblende.

Minerals identified in almost all of the analyzed samples of waste were quartz, wollastonite and sanidine. Moreover, in some of the samples the following clay minerals were present: muscovite/illite, and chamosite, as well as minerals which represent the zeolites group: philipsite, scolecite, and heulandite.

The presence of clay minerals and zeolites in the analyzed samples can play a significant role in shaping the environmental processes which occur in the waste rock heaps (Allard et al. 2012). Because of their structure, these minerals are capable of sorption of heavy metals/ /metalloids such as: $\mathrm{As}, \mathrm{Cr}, \mathrm{Fe}, \mathrm{Zn}, \mathrm{Ni}, \mathrm{Pb}, \mathrm{Cu}, \mathrm{Co}, \mathrm{Tl}$, and $\mathrm{Cd}$, therefore contributing to a reduction in the amount of elements released into the ground-water environment (Koutsopoulou et al. 2010; Kabata-Pendias, Pendias 1999). In addition to heavy metals, these minerals are also capable of sorption of radioactive elements (Misaelides 2011).

The resistance of identified minerals to weathering plays an important role in the realization of environmental sustainability (Ferrier et al. 2010; Brown, Calas 2011). Among the identified mineral groups, two classes of weathering are distinguished:

- class I - includes weathering-resistant minerals - quartz, wollastonite, muscovite/ /illite, chamosite, philipsite, scolecite, heulandite,

- class II - consists of minerals with a reduced resistance to weathering - hornblende, sanidine.

The process of releasing pollutants into water and soil will be more difficult with a large share of the waste rock minerals being resistant to weathering.

$\mathrm{X}$-ray analysis also showed the presence of uranospinite in samples of uranium. According to the classification by Bolewski (Bolewski 1965) this mineral belongs to the torbernite group. Its first discovery in Poland was in 2008 (Siuda et al. 2008).

\subsection{Content of heavy metals/metalloids in wastes}

An important criterion for assessing the impacts of waste rock on the natural environment is the content of heavy metals/metalloids in their composition. The results of this analysis are presented in Table 2.

Based on the data contained in Table 2, it can be concluded that the waste rock collected from the heaps in Kowary-Podgórze and Radoniów does not show strong variation in 
the average values of concentration of heavy metals/metalloids identified in the samples. In comparison to other heaps, only in the case of the heap in Radoniów was a decreased content of elements such as $\mathrm{As}, \mathrm{Zn}$, and $\mathrm{Pb}$ observed. This situation may result from differences in the geological structure of the two deposits.

TABLE 2

Concentration of heavy metals/metalloids in rock wastes

TABELA 2

Stężenie metali ciężkich/metaloidów w odpadach skalnych

\begin{tabular}{|c|c|c|c|c|c|c|c|c|c|}
\hline \multirow{2}{*}{ Heap } & \multirow{2}{*}{ Parameter } & \multicolumn{8}{|c|}{ Concentration of heavy metals $/$ metalloids, $\mathrm{mg} / \mathrm{kg}$} \\
\hline & & As & $\mathrm{Cr}$ & $\mathrm{Zn}$ & $\mathrm{Cd}$ & $\mathrm{Co}$ & $\mathrm{Cu}$ & $\mathrm{Ni}$ & $\mathrm{Pb}$ \\
\hline \multirow{4}{*}{$\begin{array}{c}\text { Heap } 19 \\
\text { and } \\
\text { 19a Kowary }\end{array}$} & Average & 40.88 & 41.07 & 115.66 & 2.46 & 29.34 & 31.36 & 43.23 & 139.45 \\
\hline & Minimum & 19.97 & 29.68 & 101.4 & 1.87 & 24.69 & 13.41 & 39.07 & 97.85 \\
\hline & Maximum & 82.86 & 60.57 & 137.4 & 3.28 & 37.05 & 66.11 & 50.6 & 176.14 \\
\hline & $\begin{array}{l}\text { Standard } \\
\text { deviation }\end{array}$ & 24.57 & 9.3 & 10.69 & 0.56 & 4.01 & 20.66 & 4.12 & 25.43 \\
\hline \multirow{4}{*}{$\begin{array}{l}\text { Heap } 17 \\
\text { Kowary }\end{array}$} & Average & 38.03 & 45.81 & 155.75 & 3.07 & 38.47 & 23.02 & 52.81 & 95.02 \\
\hline & Minimum & 33.83 & 27.7 & 110.9 & 2.15 & 34.35 & 19.21 & 45.72 & 67.05 \\
\hline & Maximum & 45.23 & 66.9 & 215.2 & 4.06 & 44.36 & 28.88 & 62.71 & 132.71 \\
\hline & $\begin{array}{r}\text { Standard } \\
\text { deviation }\end{array}$ & 4.37 & 15.08 & 45.2 & 0.8 & 4.04 & 3.81 & 6.9 & 21.84 \\
\hline \multirow{4}{*}{$\begin{array}{l}\text { Heap } 16 \\
\text { Kowary }\end{array}$} & Average & 31.52 & 38.88 & 140.63 & 2.56 & 34.98 & 24.49 & 51.05 & 114.33 \\
\hline & Minimum & 16.33 & 24.8 & 74.1 & 1.25 & 24.66 & 13.74 & 27.31 & 61.02 \\
\hline & Maximum & 52.93 & 58.34 & 241.8 & 3.69 & 42.04 & 41.9 & 76.56 & 173.71 \\
\hline & $\begin{array}{l}\text { Standard } \\
\text { deviation }\end{array}$ & 16.86 & 13.23 & 77.07 & 0.85 & 7.9 & 13.3 & 18.99 & 44.43 \\
\hline \multirow{4}{*}{$\begin{array}{l}\text { Heap in } \\
\text { Radoniów }\end{array}$} & Average & 9.52 & 44.36 & 69.8 & 2.43 & 32.75 & 20.73 & 44.3 & 75.1 \\
\hline & Minimum & 8.97 & 32.62 & 62.7 & 1.87 & 28.73 & 18.94 & 36.2 & 55.81 \\
\hline & Maximum & 10.18 & 59.41 & 79.8 & 4.3 & 37.81 & 25.86 & 48.72 & 120.29 \\
\hline & $\begin{array}{r}\text { Standard } \\
\text { deviation }\end{array}$ & 0.47 & 9.73 & 6.9 & 0.92 & 3.18 & 2.73 & 4.69 & 23.49 \\
\hline \multicolumn{2}{|c|}{$\begin{array}{l}\text { The concentration limits } \\
\text { for ground }{ }^{1}\end{array}$} & 60 & 500 & 1000 & 15 & 200 & 600 & 300 & 600 \\
\hline \multicolumn{2}{|c|}{$\begin{array}{l}\text { Content of elements in } \\
\text { industrial soils of study } \\
\text { area }^{2}\end{array}$} & $<5-16$ & $3-12$ & $40-1499$ & $0.5-37.3$ & $2-9$ & $7-601$ & $2-23$ & $18-514$ \\
\hline
\end{tabular}

1 Regulation of Minister of Environment from 9 September 2002 on the quality standards for soil and ground (Dz.U. Nr 156 Poz. 1359).

2 The content of elements in industrial soils of the study area (Tomassi-Morawiec et al. 1999). 
The indicated concentration of heavy metals/metalloids was compared with the limit values specified in the regulations of the Minister of Environment. These comparisons showed that almost none of the indicated concentrations of heavy metals/metalloids exceeded the limit characteristic for the type of ground. The exception was one sample taken from heap 19 and 19a, which contained higher amounts of As.

The concentration of labeled elements was also compared with the average content in the industrial soils of the research area (Tomassi-Morawiec et al. 1999). Comparative analysis showed that the concentration of As (heaps in Kowary-Podgórze), Cr, Co, and Ni identified in waste samples was much higher than the values characteristic of their average content in the industrial soils of the research area. This was connected with the naturally elevated content of these metals in the analyzed geological environment. As, Cr, Co, and $\mathrm{Ni}$ are heavy metals that have a high affinity for iron - the content of which coexisted with uranium minerals in the studied deposits.

To determine the possibility of contamination of the natural environment by these elements, the fact must be taken into account that $\mathrm{As}, \mathrm{Co}, \mathrm{Cr}$, and $\mathrm{Ni}$ are metals easily absorbed from the clay fraction. As a results, the possibility of their migration into the soil profile is limited (Kabata-Pendias, Pendias 1999; Turer 2007).

The impact of waste rock generated during the mining and processing of uranium ore on the natural environment is an issue taken into account by most countries which have problems with wastes of this type. Analysis of the chemical composition of waste rock from uranium mining was carried out in the works of Lourenco et al. 2012, Grawunder et al. 2009.

Table 3 summarizes the results of the analysis of heavy metals/metalloids determined in the waste rock collected from the heaps in Kowary-Podgórze and Radoniów, compared with analyses of waste rock from uranium mines in Portugal (Lourenco et al. 2012) and

TABLE 3

Concentration of heavy metals/metalloids in rock wastes

Stężenie metali ciężkich/metaloidów w odpadach skały płonnej

\begin{tabular}{||c|c|c|c|c|}
\hline \multirow{2}{*}{$\begin{array}{c}\text { Identified } \\
\text { metal/metalloid }\end{array}$} & \multicolumn{4}{|c|}{ Concentration of heavy metals/metalloids, mg/kg } \\
\cline { 2 - 5 } & Current study & Portugal & Germany & USA \\
\hline \hline $\mathrm{As}$ & 30.83 & - & - & 28 \\
\hline $\mathrm{Cr}$ & 42.42 & - & 30.45 & 564 \\
\hline $\mathrm{Zn}$ & 120.09 & 511.73 & 62.75 & 992 \\
\hline $\mathrm{Cd}$ & 2.62 & 2.58 & 0.3 & 52 \\
\hline $\mathrm{Co}$ & 33.54 & - & 15.35 & 4 \\
\hline $\mathrm{Cu}$ & 25.39 & - & 37.4 & 83 \\
\hline $\mathrm{Ni}$ & 47.49 & 93.38 & 48.25 & 180 \\
\hline $\mathrm{Pb}$ & 108.55 & - & - & 14 \\
\hline
\end{tabular}


Germany (Grawunder et al. 2009). Table 3 also shows the concentration values of heavy metals/metalloids in the waste rock from a phosphate mine in the United States where uranium is present in the form of a by-product (Moyle, Causey 2001).

The data contained in Table 3 suggests a large variation in the average content of heavy metals/metalloids identified in individual samples of the waste rock, resulting from variable geological conditions.

The differences in the chemical composition of the analyzed group of wastes make it impossible to introduce universal standards defining the minimum and maximum content of heavy metals/metalloids in this type of waste. At present, the fundamental legal act related to the management of mining wastes is European Union Directive 2006/21/EC of the European Parliament and the Council dated 15 March 2006, from which the provisions of the national legislation of each country were transposed.

\section{Conclusions}

X-ray analysis of samples of waste rock showed the presence of minerals in the wastes which commonly occur in the Jelenia Góra Basin area. Identified in the samples were minerals belonging to the group of zeolites and clay minerals which possess the ability of sorption of heavy metals. The identified minerals are also resistant to weathering processess, so the release of pollutants into the ground-water environment will be impeded.

Spectrometric analysis of heavy metals/metalloids confirmed the presence of As, Cr, Zn, $\mathrm{Cd}, \mathrm{Co}, \mathrm{Cu}, \mathrm{Ni}$, and $\mathrm{Pb}$ in the collected waste, but their concentrations generally do not exceed the limit values laid down in Polish regulations. Only in the case of As (heaps in Kowary-Podgórze), $\mathrm{Ni}, \mathrm{Cr}$, and $\mathrm{Co}$ did the values of their average content in the industrial soil of the research area exceed the norms.

The concentration of heavy metals/metalloids noted in waste rock from Kowary-Podgórze and Radoniów compared with the content of heavy metals/metalloids in waste from uranium mines in Portugal, and Germany, as well as a phosphate mine in the United States, showed a wide large variation in the values. This results mainly from differences in the petrographic and geological structures of the respective areas.

The analysis performed did not show that the considered group of mining wastes had a negative impact on the environment.

\section{REFERENCES}

Allard et al. 2012 - Allard Th., Balan E., Lacas G., Fourdrin C., Morichon E., Sorieul S., 2012 Radiation-induced defects in clay minerals: A review. Nuclear Instruments and Methods in Physics Research B Vol. 277, 112-120.

Bayliss et al. 1986 - B ayliss P., Erd D., Mrose M., Sabina A., S mith A.D., 1986 - Mineral Powder Diffraction File. Data Book. Swarthmore. International Center for Diffraction Data. 
B olew ski A., 1965 - Detailed mineralogy. Warszawa. Geological Publishing.

B row n G.E., Calas G., 2011 - Environmental mineralogy - Understanding element behavior in ecosystems. Comptes Rendus Geoscience Vol. 343, 90-112.

Chakrabarty-Patra et al. 2011 - Chakrabarty-Patra A., Sumesh C.G., Mohapatra S., Sahoo S.K., Tripathi R.M., Puranik V.D., 2011 - Long-term leaching of uranium from different waste matrices. Journal of Environment Management Vol. 92, 919-925.

Directive 2006/21/EC of the European Parliament and the Council dated 15 March 2006 on the management of waste from extractive industries.

Fernandes et al. 1998 - Fernandes H.M., Franklin M.R., V eiga L.H., 1998 - Acid rock drainage and radiological environmental impacts. A study case of the Uranium mining and milling facilities at Pacos de Caldas. Waste Management Vol. 18, 169-181.

Ferrier et al. 2010 - Ferrier K.L., Kirchner J.W., Riebe C.S., Finkel R.C., 2010 - Mineral-specific chemical weathering rates over millennial timescales: Measurements at Rio Icacos, Puerto Rico. Chemical Geology Vol. 277, 101-114.

Franks et al. 2011 - Franks D.M., Boger D.V., Cote C.M., Mulligan D.R., 2011 - Sustainable development principles for the disposal of mining and mineral processing wastes. Resources Policy Vol. 36, $114-122$.

Gaweł A., Mus zyń s k i M., 1996 - Tables for identification minerals by X-ray diffraction. Kraków. Publishing $\mathrm{AGH}$.

Giusti L., 2009 - A review of waste management practices and their impact on human health. Waste Management Vol. 29, 2227-2239.

Grawunder et al. 2009 - Grawunder A., Lonschinski M., Merten D., B ü chel G., 2009 - Distribution and bonding of residual contamination in glacial sediments at the former uranium mining leaching heap of Gessen/Thuringia, Germany. Chemie der Erde, Vol. 69, 5-19.

Kabata-P endias A., P endias H., 1999 - Biogeochemistry of trace elements. Warszawa. PWN.

Koutsopouluu et al. 2010 - Kouts o p o u lu u E., Papoulis D., Tsolis -Kat ges P., Kornaros M., 2010Clay minerals used in sanitary landfills for the retention of organic and inorganic pollutants. Applied Clay Science Vol. 49, 372-382.

Kreusch et al. 2005 - Kreus ch J., N e u mann W., A p pel D., D i e h1 P., 2005 - The nuclear fuel cycle. Berlin. Heinrich Böll Fundation.

Kulczycka et al. 2003 - Kulczycka J., Koneczny K., Kowalski Z., 2003 - Cost-benefit analysis for the assessment of environmental aspects of mining industry. Mineral Resources Management Vol. 19, No 4, 117-124.

Le e J., P a ndey B.D., 2012 - Bio-processing of solid wastes and secondary resources for metal extraction A review. Waste Management Vol. 32, 3-18.

Lis J., Sylwestrzak H., 1986 - Minerals of Lower Silesia. Warszawa. Geological Publishing.

Liu et al. 2011 - Liu J., Xue-Hong Z., Tran H., Dun-Qiu W., Yi-Nian Z., 2011 - Heavy metal contamination and risk assessment in water, paddy soil, and rice around electroplating plant. Environmental Science and Pollution Research Vol. 18, No 9, 1623-1632.

Lourenco et al. 2012 - Lourenco J., Pereira R., Silva A., Carvalho F., Oliveira J., Malta M., Paiva A., Goncalves F., Mendo S., 2012 - Evaluation of the sensitivity of genotoxicity and cytotoxicity endpoints in earthworms exposed in situ to uranium mining wastes. Ecotoxicology and Environmental Safety Vol. 75, 46-54.

Miecznik et al. 2011 - Mi e c znik J.B., Strzele cki R., W ołk ow ic z S., 2011 - Uranium in Poland - history of exploration and perspectives of deposit discovery. Geological Review Vol. 59, No 10, 688-697.

Mis a elides P., 2011 - Application of natural zeolites in environmental remediation: A short review. Microporous and Mesoporous Materials Vol. 144, 15-18.

Motuzas A., Vaisvalavicius R., Prosycevas I., 2002 - Application of new physical chemical methods in soil ecological investigations. Environmental Science and Pollution Research Vol. 9, No 1, 55-62.

M o y le P.R., C a u s e y J.D., 2001 - Chemical composition of samples collected from waste rock dumps and other mining-related features at selected phosphate mines in southeastern Idaho, western Wyoming and northern Utah. U.S. Geological Survey. 
Neves et al. 2012 - Neves M.O., Figueiredo V.R., Abreu M.M., 2012 - Transfer of U, Al and Mn in the water-soil-plant system near a former uranium mining area (Cunha Baixa, Portugal) and implications to human health. Science of the Total Environment Vol. 416, 156-163.

Nieć M., 2009 - The occurrence of uranium and its exploration perspectives in Poland. Energy Policy Vol. 12, z. 2/2, 435-451.

Regulation of Minister of the Environment dated 9 September 2002, on the quality standards for soil and ground (Dz.U. Nr 156 poz. 1359).

Samimi Namin et al. 2011 - S a mimi Namin F., Sh ahriar K., B a s cet in A., 2011 - Environmental impact assessment of mining activities. A new approach for mining methods selection. Mineral Resources Management Vol. 27, No 2, 113-143.

Siuda et al. 2008 - S i u d a R., Kru s zew s k i Ł., B or z ę c ki R., 2008 - Uranospinite from abandoned Podgórze uranium mine in Kowary (Karkonosze, Poland). Mineralogia - Special Papers Vol. 32.

Solecki et al. 2011 - Solecki A., Śliwiński W., Wojciechowska I., Tchórz-Trzeciakiewicz D., Syrczyński P., Sadowska M., Makowski B., 2011 - Evaluation of the possibility of occurrence of uranium mineralization in Poland based on the results of geological exploration. Geological Review Vol. 59, No 2, 98-110.

Tomassi-Morawiec et al. 1999 - Tomas si-Morawiec H., Lis J., Pasieczna A., 1999 - Geochemical atlas of Wrocław and environments. Warszawa. Państwowy Instytut Geologiczny.

Turer D., 2007 - Effect of heavy metal and alkali contamination on the swelling properties of kaolinite. Environmental Geology Vol. 52, No 3, 421-425.

Uranium mining in Poland, 2011 - Electronic access. http://www.redbor.pl/artykuly/uran.htm

Y il m a z E., 2011 - Advances in reducing large volumes of environmentally harmful mine waste rocks and tailing Mineral Resources Management Vol. 27, No 2, 89-112.

\section{ANALIZA ZAWARTOŚCI METALI CIĘŻKICH/METALOIDÓW I SKLADU MINERALNEGO ODPADÓW POCHODZĄCYCH} Z PROCESU POZYSKIWANIA KONCENTRATU URANOWEGO

\section{Słowa kluczowe}

Górnictwo uranowe, skała płonna, metale ciężkie, skład mineralny, Kowary, Radoniów

\section{Streszczenie}

Odpady powstające w procesie wydobycia i przeróbki rudy uranowej stanowią najliczniejszą grupę odpadów pouranowych. Gromadzone w postaci hałd skały płonnej i odpadów przeróbczych, ze względu na obecność w nich promieniotwórczych radionuklidów oraz pierwiastków metali ciężkich/metaloidów, stanowią potencjalne źródło zagrożenia dla ekosystemów.

W artykule przedstawiono wyniki analizy składu mineralnego oraz chemicznego skały płonnej. Określenie składu mineralnego dokonano na drodze analizy rentgenograficznej, stosując dyfraktometr HZG-4 firmy DRON. Zawartość metali ciężkich/metaloidów w próbkach odpadów oznaczona została przy użyciu metody atomowej spektrometrii absorpcyjnej. Analizie spektrometrycznej poddano następujące metale ciężkie/metaloidy: As, Cr, $\mathrm{Zn}, \mathrm{Cd}, \mathrm{Pb}, \mathrm{Co}, \mathrm{Cu}, \mathrm{Ni}$. Celem wykonanych analiz było scharakteryzowanie rozpatrywanej grupy odpadów pouranowych pod względem składu mineralnego i pierwiastkowego.

Teren badań obejmował obszar Kotliny Jeleniogórskiej, znajdujący się w południowo-zachodniej Polsce w województwie dolnośląskim. Odpady skalne pobrane zostały z hałd zlokalizowanych w miejscowościach Kowary-Podgórze i Radoniów.

Przeprowadzona analiza rentgenograficzna pobranych próbek odpadów wykazała obecność w odpadach minerałów powszechnie występujących na terenie Kotliny Jeleniogórskiej. W próbkach oznaczone zostały między innymi minerały należące do grupy zeolitów oraz minerałów ilastych, które wykazują zdolność sorpcji metali ciężkich/metaloidów. 
Analiza spektrometryczna metali ciężkich/metaloidów potwierdziła obecność w pobranych próbkach oznaczanych metali ciężkich/metaloidów, których stężenia nie przekroczyły jednak wartości dopuszczalnych, określonych w Rozporządzeniu Ministra Środowiska w sprawie standardów jakości gleby i ziemi.

Przeprowadzone analizy nie wykazały, aby rozpatrywana grupa odpadów wydobywczych miała negatywny wpływ na środowisko przyrodnicze.

CONTENT ANALYSIS OF HEAVY METALS/METALLOIDS AND MINERAL COMPOSITION OF WASTE GENERATED DURING URANIUM CONCENTRATE PROCESSING

$$
\text { Key words }
$$

Uranium mining, rock waste, heavy metals, mineral composition, Kowary, Radoniów

\section{Abstract}

Waste generated during mining and processing of uranium ore is the largest group of uranium mining wastes. Wastes collected in the forms of uranium piles, and evaporation and tailing ponds constitute a potential danger to ecosystems, because of the presence of radioactive elements and heavy metals.

This paper presents the mineral and chemical compositions of rock wastes. Determination of mineral composition was performed using a DRON HZG-4 diffractometer. The content of heavy metals in samples of waste rock was determined by atomic sorption spectrometry. Spectral analysis was applied to heavy metals/metalloids such as $\mathrm{As}, \mathrm{Cr}, \mathrm{Zn}, \mathrm{Cd}, \mathrm{Pb}, \mathrm{Co}, \mathrm{Cu}$, and $\mathrm{Ni}$. The purpose of this analysis was to characterize the groups of extractive wastes in terms of mineral and elemental compositions.

The sites examined were located in the Jelenia Góra Basin area in south-western Poland in the Lower Silesia province. Waste rock was taken from heaps located in Kowary-Podgórze and Radoniów.

$\mathrm{X}$-ray analysis of waste rock samples showed the presence of minerals in the wastes which commonly occur in the Jelenia Góra Basin area. Identified in the samples were minerals belonging to a group of zeolites and clay minerals which demonstrate the potential for sorption of heavy metals/metalloids.

Spectrometric analysis of heavy metals/metalloids confirmed the presence of $\mathrm{As}, \mathrm{Cr}, \mathrm{Zn}, \mathrm{Cd}, \mathrm{Co}, \mathrm{Cu}, \mathrm{Ni}$, and $\mathrm{Pb}$ in the collected waste, but their concentrations do not exceed the limit values laid down in the Regulation of the Minister of the Environment on the quality standards for soil and ground

The analysis performed did not show that the examined group of mining wastes had a negative impact on the environment. 